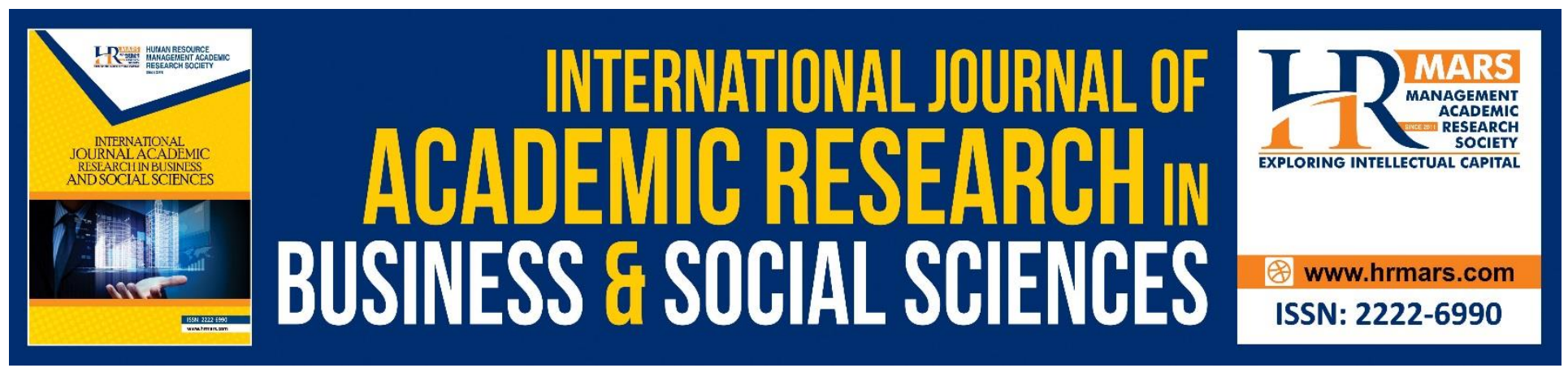

\title{
The Application of Strategy Map in the Balanced Scorecard Implementation: A Case of a Public Organization
}

\section{Hazeline Ayoup}

To Link this Article: http://dx.doi.org/10.6007/IJARBSS/v8-i8/4628

DOI: $10.6007 /$ IJARBSS/v8-i8/4628

Received: 14 June 2018, Revised: 19 July 2018, Accepted: 21 July 2018

Published Online: 28 August 2018

In-Text Citation: (Ayoup, 2018)

To Cite this Article: Ayoup, H. (2018). The Application of Strategy Map in the Balanced Scorecard Implementation: A Case of a Public Organization. International Journal of Academic Research in Business and Social Sciences, 8(8), 725-737.

\section{Copyright: (C) 2018 The Author(s)}

Published by Human Resource Management Academic Research Society (www.hrmars.com)

This article is published under the Creative Commons Attribution (CC BY 4.0) license. Anyone may reproduce, distribute, translate and create derivative works of this article (for both commercial and non-commercial purposes), subject to full attribution to the original publication and authors. The full terms of this license may be seen at: http://creativecommons.org/licences/by/4.0/legalcode

Vol. 8, No. 8, August 2018, Pg. 725 - 737

Full Terms \& Conditions of access and use can be found at http://hrmars.com/index.php/pages/detail/publication-ethics 


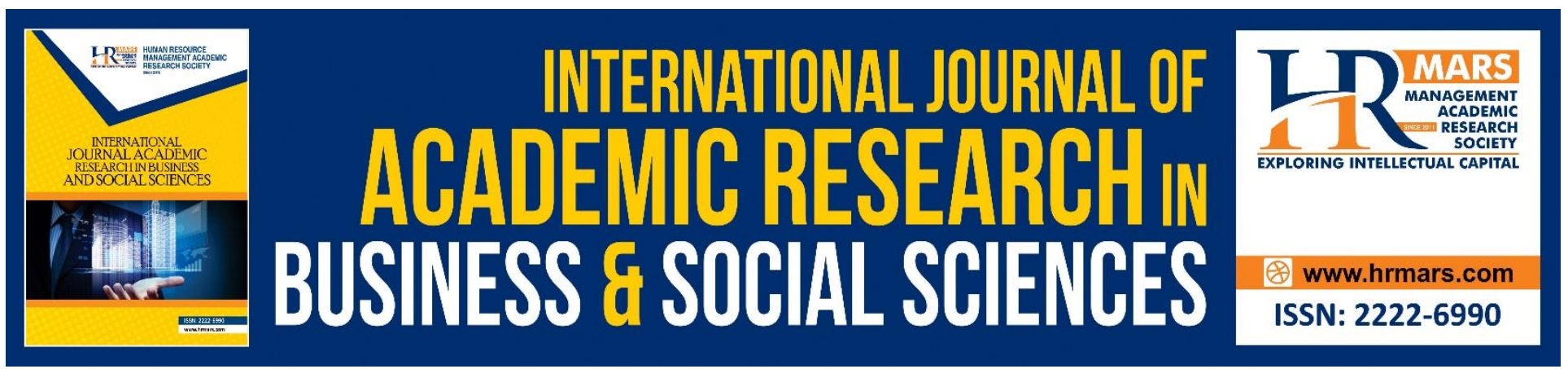

\title{
The Application of Strategy Map in the Balanced Scorecard Implementation: A Case of a Public Organization
}

\author{
Hazeline Ayoup \\ Tunku Puteri Intan Safinaz, School of Accountancy, Universiti Utara Malaysia
}

\begin{abstract}
The Balanced Scorecard (BSC) has been used as a strategic performance management tools worldwide. However, the literature shows very little evidence on some of its implementation tools such as the "Strategy Map". This paper aims to demonstrate the utilization of the strategy map in a Malaysian company which adopted the BSC as its performance management system, its implication and challenges. Using a case study approach, data were collected using observations and company's documents and was analyzed qualitatively using the thematic analysis. Result indicates that if used properly, the strategy maps help the managers to identify organizational corporate strategies, objectives and performance measurement and facilitates the process of communicating those information from the top to the lower level management until the individual level. This study emphasizes the critical role of strategy map in the BSC implementation as well as its application in other performance management system when necessary.
\end{abstract}

Keywords: Performance Management, Balanced Scorecard, Strategy Map, Qualitative Case Study, Communication Strategy.

\section{Introduction}

Managing performance is one of the vital elements in an organization. Studies indicated that a well implemented performance management system (PMS) can lead to many benefits to an organization (Aguinis \& Pierce, 2008). Among the various PMS models available, the Balanced Scorecard (BSC) has received extensive attention from the practitioners and researchers since its introduction in 1992 by Kaplan and Norton (1992) in the US. Its simplicity and practicality has driven many companies from other parts of the world to adopt this methodology into their system to manage the company's performance and to sustain its competitive advantages. The latest survey by Bain and Company (2017) shows that the BSC is still at the top ten ranking of the most popular management tools in use by organizations around the world.

After more than two decades of its development, studies have shown many implications of the BSC implementation on organizational performance from various perspectives. Previous literatures have 
shown mixed results of its implementation from performance improvement to its implementation issues. Although it is ranked top ten among popular management tool used worldwide its satisfaction rate is below average (Bain \& Company, 2017). This may due to many reasons such as the complexity of its implementation process (Dinesh \& Palmer, 2005); adopting too many indicators and failures to obtain a balance between leading and lagging indicators or non-financial and financial indicators by the implementers (Kaplan and Norton, 2001); failure to choose the appropriate non-financial performance measures (Schneiderman, 1999) and the complexity of assigning weights on its measures (Ghosh \& Mukherjee, 2006) and proper implementation processes such as the used of Strategy Map in the process (Papalexandris, Ioannou, Prastacos \& Soderquist, 2005 and Kaplan \& Norton, 2004).

Strategy Map is a crucial element for successful BSC implementation as stressed by Kaplan and Norton (2004). However, there are very limited studies on the BSC implementation which highlighted on the use of strategy map in the process despite of its important role as a framework that links organizational intangibles assets to operational processes that create higher value. Many studies have focused on its conceptual framework, the practical implication of it implementation and current studies on the BSC has moved forward to extend the original framework to integrate it with other management tools such as scenario analysis and big data analytic. To fill this gap, this study intent to understand the use of strategy map as a strategy communication tool in a Malaysian public organization. Specifically the objectives of this study are to [1] describe the used of strategy maps in the case company [2] explain the effect of the use of strategy maps in the company and [3] explain the challenges faced by the users. The results will certainly provide evidence on the BSC implementation issue with relates to the used of strategy map and highlight the advantages and drawback of its usage.

\section{BSC in Practice}

The BSC has been implemented in many companies for various purposes from performance measurement and management tools to strategic management tools. For example, Cronje and Vermaak (2004) looked at BSC as an instrument for strategic planning and performance improvement for universities in South Africa and Australia; Milis and Mercken (2004) have investigated how the BSC is used in evaluating information and communication technology projects performance; Crawford and Sealetta (2005) highlighted how the BSC could help aligning corporate social responsibility and business performance, Craig and Moores (2005) have illustrated how the BSC can be applied to manage performance of family firms, and Osama (2006) has explored the used of BSC in research and development [R\&D] process. The BSC is also used as a tool to create strategic fit as pointed by Kettunen (2006), Witcher and Chau (2007) and Bloomquist and Yearger (2008). Recent studies has expanded the used of BSC with the technology advancement. For example, Appelbaum, Kogan, Vasarhelyi and Yan (2017) proposed a Managerial Accounting Data Analytics (MADA) framework based on the balanced scorecard theory in a business intelligence context. Batocchio, Minatogawa \& Anholon (2017) recommended the combination of BSC with a method of business models representation that is the Business Model Canvas which is expected to lead to business model innovation.

Kaplan and Norton $(1992,1996,2001,2006)$ emphasized that implementing the BSC would improve firm performance. For example, the measures used by executives in the BSC companies help 
articulate the company's business strategy, communicate the strategy to different managerial levels and facilitates alignment between organizational, divisional, cross-departmental and individual initiatives to achieve common goal. The BSC can be used as a communication, information and learning system. The benefits of implementing BSC are a) it help managers to clearly identify the measures which could clearly represent organization's long term strategy; $b$ ) facilitates leaders to mobilize organizational change towards performance improvement; c) provide comprehensive framework for managers to translate companies' mission and vision into a coherent and link set of performance measures; $d$ ) improve firm ability to align its corporate, business units, support units, external partners and its board with the strategy; $e$ ) increase employee motivations towards; $f$ ) the measures can be used as a communication, information and learning system to articulate companies business strategy, communicate the strategy throughout the organization and help align individuals, departments and organizational to strive for a common goals; $g$ ) measures used provide balance between desired outcomes and the drivers of the outcomes; hard (objectives) and soft (subjective) measures; and h) BSC can be used to make explicit financial strategy of a business unit and how to customize financial objectives and measures to business unit strategy. Bloomquist and Yeager (2008) highlighted that BSC facilitates strategy communication among managers from the top to the lower level hence help aligning different organizational parts in achieving the corporate performance.

Many studies have assessed the impact of BSC implementations from various aspects and the results were varies. Some demonstrate significant impact while the others are not. Malina and Selto (2001) assessed the effectiveness of BSC as a control and communication tools. Their findings indicated that the BSC can be an effective tool for controlling corporate strategy. However as a communication tool, BSC can de-motivate employees if not carefully design and implemented. Davis and Albright (2004) compared the differences between banks branches BSC-implementers and non-implementers. Their study revealed that there are significant differences in the financial performance of the implementers and the non-implementers. Meanwhile Braam and Nijssen (2004) studied the impact of BSC implementation on the performance of the Dutch companies. They affirmed that the used of the BSC does not automatically improve firm performance. The used of BSC should be related to a firm's corporate strategy, while BSC uses which are not related to strategy may decrease firm performance. A study by Greatbanks and Tapp (2007) showed that the used of BSC within a public service city council in New Zealand has enabled employees to clearly appreciate their role and focus on delivery of performance-related measures which support the organizational strategy.

As such, being popular worldwide do not guaranteed successful implementation of the system. A study by Atkinson (2006) highlighted that only $30 \%$ of BSC implementers enjoyed the benefits of its implementation. Additionally, a survey by Rigby and Bilodeau (2009) revealed that the satisfaction rate of BSC implementers is below average. In addition, a comparative survey on the most popular management tools used by companies worldwide by Bain and Company (2009 and 2017) shows that the number of BSC users are decreasing from 66 in 2009 to 38 percent in 2017. These illustrates the need to study its implementation process that may differentiate the successful implementer and those which are not.

Kaplan and Norton $(2004,2006,2012)$ emphasized that a successful BSC implementation relies on many aspects that has been highlighted in many studies on BSC. They highlighted those aspects as for instances the leader's capability to mobilize organizational change, effective strategy maps, BSC, 
target and initiatives translation processes, ability to align corporate, business units, support units, external partners and boards with the strategy, high employee motivation towards the initiatives and good governance management and practices. Other reasons provided in another studies such as the complexity of its implementation process (Dinesh \& Palmer, 2005); adopting too many indicators and failures to obtain a balance between leading and lagging indicators or non-financial and financial indicators by the implementers (Kaplan and Norton, 2001); failure to choose the appropriate nonfinancial performance measures (Schneiderman, 1999) and the complexity of assigning weights on its measures (Ghosh \& Mukherjee, 2006) and proper implementation processes such as the used of Strategy Map in the process (Papalexandris, Ioannou, Prastacos \& Soderquist, 2005 and Kaplan \& Norton, 2004). Roest (1997) also highlighted that in implementing the BSC, there are no standard rules. BSC must be developed according to the business. BSC implementation should also be supported by the top management, starts with the company strategy, comprises of optimum number of objectives and measures, continuously improve, utilized top down and bottom up approach, aware of the effects of key performance indicators (KPIs) on employees' behavior and acknowledge the facts that not all measures can be quantify. Among all, the used of strategy map in the implementation process gain less attention from the researcher.

\section{The Strategy Map}

Kaplan and Norton, the founder of the BSC write a 454 pages book titled "Strategy Maps: Converting the Intangibles Assets into Tangible Outcomes". This indicates the importance of the strategy maps in the BSC implementation process. Developing strategy map is vital in the BSC implementation process. Kaplan and Norton (2004) explained that strategy map provides the visual framework for integrating the organization's objectives in the four BSC perspectives. It illustrates the cause-andeffect relationships which link the critical learning and growth and internal business process to the desired outcomes in the customer and financial perspectives. It is based on five basic principles that are 1) the strategies must create a balance between any contradiction between it for instances between striving for growth and managing cost; 2 ) strategies must focused on various perspective of customer value proposition; 3) value is created through the internal business process; 4) the strategies consist of simultaneous, complementary themes and 5) the alignment between strategies determines the value of the company's intangible assets. Scholey (2005) contended that strategy map is a part of the solution to better strategy formulation and execution. However, study on the application of strategy map is very limited especially in Asian company. For example; Chan (2009) studied the application of strategy map in healthcare sector in Canada while Quezada, Cordova, Palominos, Godoy and Ross (2009) described the BSC as a tool to identify strategic objectives in developing strategy maps in Chile. Another study on strategy map was conducted by Buytendijk, Hatch and Micheli (2010) who proposed that scenario analysis could facilitate the process of building strategy map. Mittal (2016) demonstrate the used of strategy maps to derive and implement a customer-focused strategy in banks via the Customer-Satisfaction-Strategy Map (CSSM). Figure 1 below illustrate an example of a Strategy Map of an organization. 
INTERNATIONAL JOURNAL OF ACADEMIC RESEARCH IN BUSINESS AND SOCIAL SCIENCES Vol. 8, No. 8, August 2018, E-ISSN: 2222-6990 C 2018 HRMARS

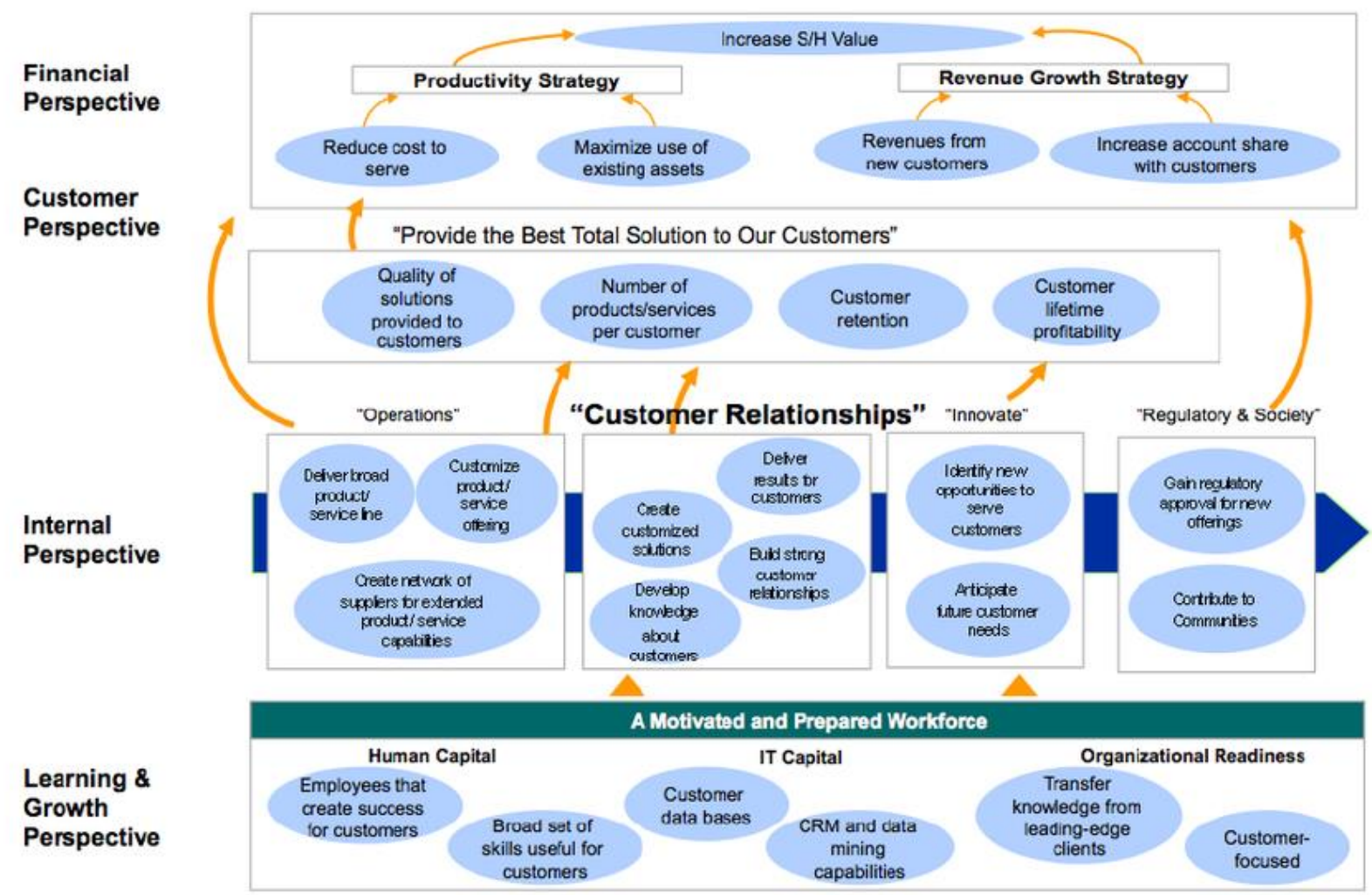

Figure 1. Template of a strategy map (Kaplan and Norton, 2004, p. 331).

Thus, using a case study approach, this study attempts to investigate BSC implementation, focusing particularly on the application of strategy maps as a tool to communicate strategy at every level in a large Malaysian Corporation.

\section{Research Design}

This study adopted the qualitative case study approach to explore the used of strategy map in BSC implementation. Data was gathered through a series of observations in 13 management meetings and analysis of company's internal documents such as BSC implementation guideline and performance reports. Specifically, this study aims to provide detailed narration on how the case company used strategy maps in order to ensure effective BSC implementation process and gain the most benefits from the initiative.

The case company selected for this study is a large multinational public organization which has been using the BSC for more than ten years. The company headquarters is located in Kuala Lumpur. It has been awarded as one of the winner for National Award for Management Accounting (NAfMA) practices for its extensive used of various management accounting tools including the BSC. However, the name of the company is kept confidential and named as Company XYZ due to ethical consideration.

An observation of the real implementation process in an organizational context is chosen as the data collection strategy following Creswell (2007) to achieve the two objectives of this study that are to [1] describe the used of strategy maps in the case company and [2] described the factors affecting 
INTERNATIONAL JOURNAL OF ACADEMIC RESEARCH IN BUSINESS AND SOCIAL SCIENCES Vol. 8, No. 8, August 2018, E-ISSN: 2222-6990 @ 2018 HRMARS

effective used of the strategy maps. The researcher was granted permission by the Chief Executive Officer [CEO] and the human resource division of the case company to undergo a three month attachment program as part of a "win-win" initiative. Observations and analysis of documents have been identified as the most appropriate data gathering strategies due to their ability to capture a more realistic and true information direct from the sources itself. Moreover, this approach can mitigate the possibility of human biasness of providing information as compared to questionnaire survey see Creswell (2007 and Yin (1998).

Table 1. List of Observations in Company XYZ BSC Meetings

\begin{tabular}{|c|c|}
\hline No & Agenda \\
\hline 1 & Meeting with the managers in the XYZ Performance Management Office (PMO) \\
\hline 2 & Meeting to develop Group PMO strategy maps and scorecard. \\
\hline 3 & Meeting with the line of business BSC representatives. \\
\hline 4 & Meeting with the Group Customer Service Management Department. \\
\hline 5 & Marriot Putrajaya. BSC Cascading Workshop XYZ Subsidiary. \\
\hline 6 & BSC computerised system training (in Subsidiary). \\
\hline 7 & BSC Cascading Workshop for XYZ BSC Resource Group (BSR). \\
\hline 8 & BSC Cascading Workshop for XYZ BSR. \\
\hline 9 & BSC Cascading Workshop for XYZ BSR. \\
\hline 10 & Sharing session on human resources PMO managers within the PMO group. \\
\hline 11 & Meeting with XYZ training centre \\
\hline 12 & Meeting with the CSM - customer service management unit. \\
\hline 13 & XYZ SBU challenges session. XYZ Strategic Business Unit (SBU) and BSC unit. \\
\hline 14 & Chief Technology and Information Officer (CTIO) BSC alignment meeting. \\
\hline 15 & Update Session within the PMO unit \\
\hline 16 & Challenge Session between support departments with the PMO. \\
\hline 17 & $\begin{array}{l}\text { BSC computerised system and BSC Training for information technology department managers and } \\
\text { PMO. }\end{array}$ \\
\hline 18 & The high level KPIs challenge session -chaired by the CEO. \\
\hline 29 & PMO and Group Finance GM \\
\hline 20 & Internal BSC PMO meeting \\
\hline 21 & Meeting with Group Products Development \\
\hline 22 & Meeting Alignment Matrix \\
\hline 23 & Challenge meeting XYZ SBU. \\
\hline 24 & Meeting Group Quality Management \\
\hline 25 & Meeting with Business Functions and Central Functions \\
\hline 26 & Meeting PMO -updates \\
\hline 27 & Meeting between NO/ND and Customer Service Management \\
\hline 28 & Leadership talk \\
\hline 29 & Meeting with legal compliance \\
\hline 30 & BSC Reporting Session \\
\hline
\end{tabular}

The attachment program was very timely as the company was just at the early stage of the BSC new cycle. The attachment session has enabled the researcher to take part as an observer in various management meetings related to BSC implementation including the development of company and divisional strategy maps. There were many different meetings that discussed on the development of departmental strategy maps \& scorecard; the selection of performance measures; the development of detailed definitions of each measures; the aligning of different divisional objectives and measures. The researcher was also allowed to observe and participate in various in-house and other computer- 
based training sessions. In addition, the researcher was given the opportunity to review the BSC performance management system and how it was used for tracking, contracting and evaluating employees' performance. The observed events were recorded in a log book. Based on the observations and documents available, the BSC implementation and the application of strategy maps were analyzed based on themes.

\section{Research Findings and Discussion}

\section{The Development of Strategy Maps in Company XYZ}

In order to understand the application, impact and challenges faced by the case company in using the strategy map in the process of implementing the BSC, it is vital to understand the process of developing the map itself. Basically, Company XYZ's strategy map consist of its corporate level strategic themes and strategic objectives based on the BSC four perspectives. The objectives for each perspectives are tied to the strategic themes to ensure the alignment between them. Next, the corporate strategy map which layout the company's main themes and objective is shared and carry by the other corporate center, branches, departments and subsidiaries in their strategy maps. This is to ensure that the company's vision and mission are communicated to every division, unit and individual in the organization.

The company's corporate goal is the central basis of developing each strategy map. Base on the four BSC perspectives, strategic themes relevant to that perspective is developed following the determination of appropriate strategic objectives that can best support the strategic themes and company main goal. In every strategy map development process these are the most commonly asked questions among managers:

a) What is the best objective for the given strategic theme?

b) Does the objective support the division upper level objectives?

c) Can the objectives be measured?

d) Can the measures be capture by the company's system?

Observations and performance report shows that the strategy map is used as the core for BSC implementation process in the company. Utilizing BSC methodology requires the company to initially create its vision, mission and strategy to ensure that company's vision and mission can be translated into objectives and measures. This is clearly presented through the company strategy map. It is very important at this stage for the top management to clarify the vision and mission to the middle managers who are responsible to implement the strategy.

\section{The Used of Strategy Maps in Company XYZ}

As mentioned in the above section, this research is a case study which was conducted in a large multinational public organization in Malaysia that has been using the BSC for more than ten years. To answer the first research objective that is to describe the used of strategy map in the organization, observations and company's documents indicates that the "Strategy Map" is used firstly as a tool to develop and link the company's strategic objectives based on the four BSC perspectives. This is the first step in the BSC development and implementation process which requires detail understanding of the organization's vision, mission, core business, strength and weaknesses and the customers' demands. Failure to identify appropriate strategic objective for each perspective at this level may lead to the creation of ineffective strategy map and strategy implementation at the lower level. 
Having the company's top management level strategy map ready, it is then used as a tool to communicate company's strategic objectives to the company's strategic business units, support units and division. It is formally used as the main source of reference to communicate the broad company vision, mission and objectives to the other parts of the organization. Through observation, it is very clear that the strategy map is the main BSC strategic objectives communication tool. It was regularly presented in most of the BSC briefing sessions. Their aim is to clarify company's strategic objectives to every manager involved. However, the application of strategy map is only compulsory at the divisional levels. It is not translated up to the individual level. Therefore the linkages flow only at the top level and middle management level which impede successful strategy communication process between top, middle and operational level managers.

Thirdly, the "Strategy Map" is also used to create vertical and horizontal strategic alignment of strategies and objectives in the organization. To ensure the top level strategy is communicated to the lower level and also interdepartmental level, the development of divisional strategy map must be based on the higher managerial level in the hierarchy. In the case company it is named as "Tier". The top tier strategy will flow down to the lower tier to the individual level through the strategy map. The linkages were then assessed by the responsible head of division to ensure every objective exist in the map has its linkages to the upper level objectives. Besides assessing the linkages with the upper level, the linkages between the departments at the same level should and can also be assessed. However, it is observed that more emphasized were given to the vertical linkages compared to the horizontal linkages.

\section{The Challenges}

Developing and using the strategy maps as a tool to communicate organizational strategies has its own challenges. Observations have highlighted four challenges in developing a good strategy map for communication purposes. The main challenge faced by the managers is their understanding of the conceptual framework of the strategy map itself. Although in the early BSC implementation stage head of department and managers were sent for BSC training and workshop, they gained different understanding of the strategy map concept and fundamentals. In addition, many of the BSC training focused more on the four perspectives with less emphasized on the map.

Comparative analysis of the company's strategy map and its divisional strategy maps indicates that in many cases, the divisional maps were merely copied from the original map provided by the headquarters with little consideration on its overall congruency. In addition, the divisional strategy maps were developed in isolation within the individual division. The access to the other division's strategy map is not made available throughout the organization. It is only available by request thus, hamper the creation of an effective strategy maps between divisions which lead to miscommunication of proper information through the maps. Though the development processes are carefully design and implemented, communication leakage still occurs between different divisions. For example, Division A and B have developed their own strategy map based on company strategy map. However, in providing services, there are interdependencies between divisions. It is highly observed that very limited communications exist between the two divisions in the strategy map development process. 
The second challenge faced by the managers is the judgmental nature of the process of identifying appropriate themes for each BSC perspectives and its linkages with the other themes in the map. Although the top management has formally developed a very structured strategy maps development guide for its managers, the determination of strategic objectives is highly dependent on managers' judgment. The company has its own BSC implementation policy and guideline which is internally built by the strategic office. This guideline facilitates the strategy maps development process. It contains guideline on the suggested design of the strategy maps, how the strategic themes are created and used, the formulation of strategic objectives, ways to identify good performance indicators for the objectives and its interdependencies to other elements in the map. It also illustrates how managers should determine its strategic initiatives to ensure attainment of its objectives. Though policy and guideline has been developed, all these activities are highly dependent on managers' judgment based on managers' knowledge and experience in the business. Therefore, clarity of the themes and objectives is still subject to individual interpretation.

Thirdly, the managers will have to ensure that the objectives that are placed in the map can be measured objectively for the implementation and monitoring purposes. This is another challenge especially for the non-financial objectives. To ensure measurability of each strategic objectives which has been set in the strategy maps, managers who are involved in the development of the map has to define the objectives and design the measurement. Issues arise when the managers have to define the measurement for their administrative and clerical level staff which are not financial in nature. These requires detail analysis of the core business of the divisions, departments and unit. At the individual employees' level, the managers have to analyze the job specification of each employees which requires knowledge, time, effort and persistency. Though the definition of all objectives and measures are defined at all levels, its documentation and data and information management system need to be improved. The definition database is kept in softcopy file which are only accessible to relevant managers. The initial aim of developing the database is to ensure effective communication of objectives to every level as its usage among managers is very limited.

Finally, the managers' perception towards BSC and its implementation has also affected the process. Though managers agree that BSC benefited their company in streamlining their objectives at every level, communicating of company's strategy through strategy map is not sufficient. Managers view strategy maps as a high level management tool which has little connection to them. Managers at the operational level show less interest on the strategy maps which hold back communication of strategy from top to the lower level.

\section{Conclusion and Limitation}

The applications of the strategy maps in facilitating a good strategy development and implementation process was emphasized by Kaplan and Norton (2004) in their BSC implementation guideline. However, the company's experience in developing and using the maps is limited in the literature. This study highlighted the experience within a public organization in Malaysia. It reveals that applying the strategy map in organizational strategy development and performance management process helps the organization to critically identify their core vision, mission and objectives. It also helps to streamline the themes and objectives within a map and between the departmental maps. Additionally, the maps also become a useful communication tools to communicate an organization's corporate objectives to the lower management level. These is in line with other studies by 
However, studies reported various means of using strategy map in BSC companies Kunc (2008); Chan (2009); Buytendijk, Hatch and Micheli (2010); Appelbaum et al. 2017and Batocchio et al. (2017). The Strategy Maps can be an effective way to communicate organization's strategy to managers if it is flexibly used and clear where formal definitions of objectives are made available to all managers. Companies should design an effective and efficient way of using the strategy maps not only as the top management tool but middle and operational managers should be encouraged to have their personal strategy maps which indirectly force them to understand their divisional and company objectives. However, using the strategy maps as a strategy development, implementation and communication tools requires managers to spend time and effort in its development stage. Thus managers must not be caught in the formal process as the business on the ground should be their main priorities. The main limitation of this study is that it is based on a single case study which limit its ability for generalization. More study on the application of strategy maps in other organization is needed. Future study may also try to provide strategy maps usage guideline to ensure its full utilization in a BSC company as Kaplan and Norton (2004) themselves provided a very general guideline. In addition, a study can be conducted to look into the application of the strategy maps framework into the other performance management system in the market.

\section{Acknowledgement}

The author wish to thank Prof Dr Normah Omar and Prof Dr Ibrahim Kamal Abdul Rahmah from Universiti Teknologi Mara Shah Alam, Malaysia for their guide in completing this study. Also to the Ministry of Higher Education, Malaysia for sponsoring the study.

\section{Corresponding Author}

Hazeline Ayoup, Tunku Puteri Intan Safinaz School Accountancy, College of Business, University Utara Malaysia, Malaysia, Email: hazel@uum.edu.my.

\section{References}

Aguinis, H., \& Pierce, C. A. (2008). Enhancing the Relevance of Organizational Behavior by Embracing Performance Management Research. Journal of Organizational Behavior: The International Journal of Industrial, Occupational and Organizational Psychology and Behavior, 29(1), 139145.

Ahn, H. (2001). Applying the Balanced Scorecard Concept: An Experience Report, Long Range Planning, 34, 441-461.

Appelbaum, D., Kogan, A., Vasarhelyi, M., \& Yan, Z. (2017). Impact of Business Analytics and Enterprise Systems on Managerial Accounting. International Journal of Accounting Information Systems, 25, 29-44.

Atkinson, H. (2006). Strategy Implementation: A Role for the Balanced Scorecard? Management Decision, 44(10), 1441-1460.

Batocchio, A., Ferraz Minatogawa, V. L., \& Anholon, R. (2017). Proposal for a Method for Business Model Performance Assessment: Toward an Experimentation Tool for Business Model Innovation. Journal of Technology Management \& Innovation, 12(1), 61-70.

Bloomquist, P., \& Yeager, J. (2008). Using Balanced Scorecards to Align Organizational Strategies. Healthcare Executive, 23(1), 24-28. 
INTERNATIONAL JOURNAL OF ACADEMIC RESEARCH IN BUSINESS AND SOCIAL SCIENCES

Vol. 8, No. 8, August 2018, E-ISSN: 2222-6990 @ 2018 HRMARS

Braam, G. J., \& Nijssen, E. J. (2004). Performance Effects of Using the Balanced Scorecard: A Note on the Dutch Experience. Long Range Planning, 37, 335-349.

Buckingham, M., \& Goodall, A. (2015). Reinventing Performance Management. Harvard Business Review, 93(4), 40-50.

Buytendijk, F., Hatch, T., \& Micheli, P. (2010). Scenario-based Strategy Maps. Business Horizons, 53, 335-347.

Chan, Y. C. L. (2009). How Strategy Map Works for Ontario's Health System. International Journal of Public Sector Management, 22(4), 349-363.

Craig, J., \& Moores, K. (2005). Balanced Scorecard to Drive the Strategic Planning of Family Firms. Family Business Review, 18(2), 105-122.

Crawford, D., \& Scaletta, T. (2005). The Balanced Scorecard and Corporate Social: Aligning Values. CMA Management, 79(6), 20-27.

Creswell, J. W. (2007). Qualitative inquiry and research design: Choosing among five approach (Vol. 2). London: Sage Publication.

Cronje, C. J., \& Vermaak, F. N. S. (2004). The Balanced Scorecard as a Potential Instrument for Supporting Planning and Improvement in Accounting Education: Comparative Survey Findings. SAJEMS NS, 7(3), 480-491.

Davis, S., \& Albright, T. (2004). An Investigation of the Effect of Balanced Scorecard Implementation on Financial Performance. Management Accounting Research, 15, 135-153.

Dinesh, D., \& Palmer, E. (1998). Management by Objectives and the Balanced Scorecard: While Rome Falls Again? Management Decision, 36(6), 363-369.

Ghosh, S., \& Mukherjee, S. (2006). Measurement of Corporate Performance through Balanced Scorecard: An Overview, Vidyasagar University, Journal of Commerce, 11, 60-70.

Greatbanks, R., \& Tapp, D. (2007). The Impact of Balanced Scorecards in a Public Sector Environment: Empirical Evidence from Dunedin City Council, New Zealand. Industrial Journal of Operations and Production Management, 27(8), 846-873.

Kaplan, R. S., \& Norton, D. P. (1992). The Balanced Scorecard - Measures that drive performance. Harvard Business Review.

Kaplan, R. S., \& Norton, D. P. (1996a). The Balanced Scorecard: Translating strategy into action. Boston Massachusetts: Harvard Business School Press.

Kaplan, R. S., \& Norton, D. P. (1996b). Linking the Balanced Scorecard to strategy. California Management Review, 39(1), 53-79.

Kaplan, R. S. \& Norton, D. P. (2001a). Transforming the Balanced Scorecard from Performance Measurement to Strategic Management: Part I. Accounting Horizons, 15(1).

Kaplan, R. S., \& Norton, D. P. (2001b). The Strategy Focused Organization: How Balanced Scorecard Companies Strive in the New Business Environment. Massachusetts: Harvard Business School Press.

Kaplan, R. S., \& Norton, D. P. (2004a). The Strategy Map: Guide to Aligning Intangible Assets. Strategy and Leadership, 32(5), 10-17.

Kaplan, R. S., \& Norton, D. P. (2004b). Strategy Maps: Converting Intangible Assets into Tangible Outcomes. Massachusetts: Harvard Business School Press.

Kaplan, R. S., \& Norton, D. P. (2006a). Alignment: Using the Balanced Scorecard to Create Corporate Synergies. Massachusetts: Harvard Business School Press.

Kaplan, R. S., \& Norton, D. P. (2006b). Response to S. Voelpel et al.,"The Tyranny of the Balanced Scorecard in the Innovation Economy". Journal of Intellectual Capital, 7(1), 43-60. 
INTERNATIONAL JOURNAL OF ACADEMIC RESEARCH IN BUSINESS AND SOCIAL SCIENCES

Vol. 8, No. 8, August 2018, E-ISSN: 2222-6990 @ 2018 HRMARS

Kettunen, J. (2006). Strategies for the Cooperation of Educational Institutions and Companies in Mechanical Engineering, Industrial Journal of Educational Management, 20, 19-28.

Kunc, M. (2008). Using Systems Thinking to Enhance Strategy Maps. Management Decision, 46(5), 761-778.

Kaplan, R. S. (2012). The Balanced Scorecard: Comments on Balanced Scorecard Commentaries. Journal of Accounting \& Organizational Change, 8(4), 539-545.

Malina, M. A., \& Selto, F. H. (2001). Communicating and Controlling Strategy: An Empirical Study of the Effectiveness of the Balanced Scorecard. Retrieved from http://papers.ssrn.com/sol3/papers.cfm?abstract_id=278939

Milis, K., \& Mercken, R. (2004). The Used of the Balanced Scorecard for the Evaluation of Information and Communication Technology Projects. Industrial Journal of Project Management, 22, 87-97.

Mittal, V. (2016). Developing and Implementing a Customer-Focused Strategy in Banks: Customer Satisfaction Strategy Maps.

Osama, A. (2006). Designing Strategy and Measuring Performance in R\&D: The Case of Balanced Scorecards, unpublished PhD Dissertation, Fredrick S. Pardee-RAND Graduate School, Santa Monica.

Papalexandris, A., loannou, G., Prastacos, G., \& Soderquist, K. E. (2005). An Integrated Methodology for Putting the Balanced Scorecard into Action. European Management Journal, 23(2), 214-227.

Quezada, L. E., Cordova, F. M., Palominos, P., Godoy, K., \& Ross, J. (2009). Method for Identifying Strategic Objectives in Strategy Maps. International Journal of Production Economics, 122, 492500.

Rigby, D., \& Bilodeau, B. (2009). Management tools and trends 2009: Bain and Company.

Roest, P. (1997). The Golden Rules for Implementing the Balanced Scorecard. Information Management \& Computer Security, 5(5), 163-165.

Schneiderman, A. M. (1999). Why Balanced Scorecards Fail. Journal of Strategic Performance Measurement, 2(11).

Scholey, C. (2005). Strategy Maps: A Step-by-step Guide to Measuring, Managing and Communicating the Plan. Journal of Business Strategy, 26(3), 12-19.

Witcher, B. J., \& Chau, V. S. (2007). Balanced Scorecard and Honshin Kanri: Dynamic Capabilities for Managing Strategic Fit. Management Decision, 45(3), 518-538.

Wu, H. Y. (2012). Constructing a Strategy Map for Banking Institutions with Key Performance Indicators of the Balanced Scorecard. Evaluation and Program Planning, 35(3), 303-320.

Yin, R.K. (1998). Case Study Research: Design and Methods. D. S. Foster. London: SAGE Publications. 